\title{
IMPACT OF BRANDING ON CONSUMER BUYING BEHAVIOR IN THE CLOTHING INDUSTRY: AN INDIAN PERSPECTIVE
}

\section{ARITRA RAWAT}

Symbiosis Institute of Business Management Bengaluru (SIBM), Symbiosis International (Deemed University) (SIU), Electronic

\author{
City, Hosur Road, Bengaluru, Karnataka, India
}

\begin{abstract}
In the modern world, branding is one of the most crucial elements which affect consumer choices. Fascinating it is to understand the mechanism of how branding can affect the purchasing decision and other behavior still remain elusive. The intend of this research is to observe the effect of various branding factors also, how it influences the consumers buying decisions of brands and to provide in-depth knowledge about the factors (brand image, price, brand awareness, advertisement, and brand loyalty) which affect the most during consumer buying decision. Hypothesis framed was tested by collecting data from customers. Also, the study not only examines the factor which consumers prefer while buying clothes (i.e. quality, price, design, brand name) but also to find the relation between the social-demographic variables like (Age, Gender, Income, and occupation) and their behavior to buy branded clothes. Also, the study will highlight which brand do consumers prefer with respect to the origin (foreign brand vs international brand). The study has revealed that the most important branding strategy is brand image followed by brand awareness and for building a successful brand the most important factor was quality as most of the consumers give preference to quality followed by price while they buy a brand.
\end{abstract}

KEYWORDS: Branding, Consumer Purchase Behavior, Brand Image, Brand Awareness, Advertising, Perception

Received: Jun 08, 2020; Accepted: Jun 28, 2020; Published: Sep 11, 2020; Paper Id.: IJMPERDJUN20201167

\section{INTRODUCTION}

In the past few decades, we have absorbed the understanding of the different factors that affect consumer judgments about brands and the processes which underlie choosing a specific brand. Considering the domain of branding. There are numerous kinds of literature on branding which has amassed more than a hundred studies in leading journal, these studies have identified various determinant which affects the customer's perception toward a given brand. Branding can be acknowledged as one of the most crucial and fascinating strategies, which can be used for wining over competitors. In today's modern world, time is changing swiftly, and so the marketing strategies that are being adopted by various firms to stay competitive in the market. Organizations continuously seek to comprehend the buying behaviour of consumers which can help them to grow and predict future trends. Gradually, organizations are now changing their focus from the market line or products to marketing strategies and consumers. In the modern world, an organization emphasizes consumer display with regards to the 4P's of marketing (Product, Price, Promotion, and Place). Today, clothing brands have turned into a status symbol. More and more customers across the globe choose branded apparel. But the question is, why? Marketers use various branding techniques to get a competitive and sustainable advantage. 


\section{LITERATURE REVIEW}

According to Kim and Kahle (2006), today, the market is very competitive and there is an intense competition to acquire consumers and the trend is increasing. This competitive environment enables consumers with many options and to choose from a variety of products. They stated that in such a dilemma consumers' ultimate decision is determined by various other factors. Additionally, a well-known brand image is very essential assets an organization can possess. Brand and branding are very powerful tools to create a long sustainable competitive advantage. There are several elements which impact the buying intention of consumers, these elements can be intrinsic as well as extrinsic in nature, some of the internal factors can be interpersonal thoughts, perception, lifestyle. Besides, some external factors are income, price, quality, and reference groups.

\section{Brand}

"Brand is the intangible sum of a product's attributes", words of David Ogilvy, father of the advertisement. Brands are built over a long period by the image individual has of an organization. Brands are important to an organization as they are an asset that generates cash flows, they are protected and shielded against replicating. An organization creates brands to captivate and retain consumers by promotion, value, status, and image. Brands introduce stability to the business thus it helps and guards an organization against competitive erosion. Brands are novel, distinct, non-replaceable, and give a continuous long-term competitive advantage. Creating a brand and portraying a positive image is not enough; an organization has to deliver a good experience. According to Schimmit (1999), the approach to branding can be classified into two ways; the first approach, looking at brand as an identifier, here logo, slogans, and names create consumer awareness and builds a particular image of a brand which consumers remember. The second approach, looking at a brand as experience provider, here logo, name, and slogans provide consumers an affective relation and lifestyle with the brands.

\section{Branding}

Branding act as a signal which helps customers to quickly spot a product which they like. It helps to recognize and differentiate the product from other products by providing relevant information. This information can be about brand perception or brand awareness. In the modern era, branding has become an integral and important aspect when it comes to the formulation of business strategy. It not only focusses on creating an image also on customer value. According to (Hislop, 2001), Branding can be defined as a process of establishing a partnership or a bond between an organization product and emotional perception of consumers, in order to generate differentiation between competition and simultaneously strengthening brand loyalty. This helps in ensuring that an organization is developing a competitive advantage over competitors and simultaneously building brand loyalty among consumers.

\section{Brand Awareness}

According to Rossiter and Prey (1987), in the process of buying, brand awareness is ahead of all other processes. Brand awareness is one of the important and foremost prerequisite factor of brand knowledge in the consumer mind, it represents the magnitude to which consumers can identify a brand. It can be further classified into; brand recognition (the magnitude of consumers to which they can corroborate any prior exposure to a brand attribute) and brand recall (the magnitude of consumers to which they can identify and recover an image or a quality when provided a product). It plays a very important character while consumer makes a purchasing decision. When consumers choose to buy a product in any 
category it is very essential that they should recall the brand. According to (Keller, 1998), brand awareness can potentially impact the consumer buying decision by effecting the brand associations which make up the brand image

\section{Brand Loyalty}

Brand loyalty can be acknowledged as a brand, having a strong position when compared against competitors thus refrain consumers to purchase from a competitor. According to Chaudhuri (1997), brand loyalty is the priority of consumers to purchase one brand or to purchase a specific brand name thus it affects consumer choice towards the brand to a high extent. High brand loyalty makes the possibility of customers switching to other brands very low, also it encourages customers to purchase the same brand frequently. A high magnitude of loyalty shows the propensity to buy one brand. As consumers become more loyal to the brand, the more they will perceive the brand as of high quality and they will buy a specific brand on a regular basis. According to Keller (2003), customers buy similar brands frequently but they are not brand loyal. They purchase the mere reason of their habits, perception, promotion, or reference group.

Customers favor the brand which fulfills their needs. The consumer who is most loyal to brands is known as committed buyers. These consumers buy the brand because there is proximity between the brand and their personal values. It is crucial and foremost assets to an organization thus aid an organization to reduce its marketing expenditure, as these loyal consumers show preference to the frequent purchase of similar brand thus cost less to an organization as it doesn't have to put an extra effort to collect and find new consumers for purchasing the similar brand.

Brand loyalty can be categorized as the loyalty of consumers into Soft-core, switcher, hard-core, and shifting.

- Soft Core - These are the kind of consumers who are loyal to more than one brand. Their buying behavior can be depicted as $(11,12,22)$ for any two brands.

- Hard Core - These are the kind of consumers who are loyal to a single brand. Their buying behavior can be depicted as (1).

- Shifting - These are the kind of consumers who can divert from one brand to another brand. The buying behavior can be depicted as ( 1 to 2 ) for any two brands.

- Switcher - These are the kind of customers who have no exhibit no loyalty for any brands. The buying behavior can be depicted as $(13,41,52)$ for any five brands.

\section{Brand Image}

According to Keller (1993), the brand image can be stated as a whole reflection and apprehension of the product which consumers have in their mind. It is an intangible asset that helps to create an image that is remembered by customers thus easily recalled by people. Brand image is an ideology and belief towards any individual brand; thus, it is the perception of consumers about the product. It is how an individual brand is positioned among the target audience and emphasizes the product character isa very distinctive way from the competitors. Consumers generate various associations with the brand thus it helps the consumer to decide which brand is better for them thus become the deciding factor, which brands to choose over others. Brand Image can be reinforced by using tools like an advertisement, word of mouth, etc. 


\section{Advertising}

Advertising is a marketing phenomenon that is which play an integral role in conveying the message of an organization to its consumer. Consumers don't even realize how they get affected by advertisements and how they can influence their buying decisions. In today's highly competitive market, the right advertisement provides a competitive edge over the competitor. According to Jefkins (1973), advertisements enable an organization to provide the most convincing selling message to the consumers for the products they are offering at the lowest cost. According to Niazi, Siddiqui, Alishah, and Hunjra (2012), it is a very useful tool for attracting consumers and divert their point of view as positive towards a brand. It can vary from a short clip to a picture stating a few words so as to encourage consumers to buy a product. Advertisement is a mysterious swirl where an organization drains billions of dollars in the hope that they won't lose their market share. It's a huge investment still nobody has a clear idea of what they are actually getting in return, failure of the ad campaign can lower the profits thud affecting the ROI.

\section{Pricing}

The pricing of the products may impact the purchasing decision of consumers and sometimes can be a game changer, whether they purchase the product or not. To attract the consumers, Stores like Wal-Mart, created an image and made the perception among consumers to charge lowest. Few consumers prefer buying the products exclusively based on price. But in some cases, consumers are willing to even pay more as they believe and give more importance to quality. According to previous research, the brand experience and prior knowledge of the brand ora product can enhance the impact of price on consumer decisions (Grewal et al., 1998). Also, consumers think that highly admired and quality products will attract a higher price. According to (Labeaga et al., 2007), research shows that low prices and frequently purchased products carry more loyalty. Discount and promotion are frequently used strategies to attract consumers. Apart from these strategies, an organization may opt for other pricing strategies like odd pricing (setting price to Rs199, Rs999), bundle pricing (buy one and get one free)

\section{Perceived Quality}

Quality plays one of the key roles in decision making, there is an interrelationship between the price and the quality which a brand offers. The consumer perception about brand quality can be measured by consumer belief about the product the attributes, quality, and performance of the products. Thus, perceived quality can help to add additional value to the brands by offering the customers a drive to buy, position themselves differently from competitors and charging premium prices It is noticeable that a strong brand has high prices thus consumers think, high prices are a sign of high quality. According to (Uggla,2001; Aaker 1991), when the consumer perceive that the brand offers high quality, then most likely they will buy the product offered by the brand because of its quality. According to many researchers, there is a positive association between the perceived quality and brand loyalty, the quality offered by brand assures and satisfies the consumer which therefore encourages them to repurchase from the same brand thus leads to band loyalty. This perceived quality offered by the brand can influence the buying decision of consumers. Providing good quality attract higher pricing which means superior gross margins and profit.

\section{Consumer Behavior}

According to (Loudon and Della Bitta, 1980), consumer behaviorcab be defined as the study of any individual and groups regarding the activities and decision-making process they involved in while evaluation, purchase, use or disposal of 
product and services. Consumer behavior encompasses the in-depth study of various factors like why, when, where, and how consumers buy products. For consumers, the framework mainly consists of factors like brand image, brand awareness, price. According to the research done by (Farris et al., 2010), the decision to purchase a product based on a cognitive level is remarkably affected by the brand image and brand awareness. Many attributes affect consumer views thus understanding consumer behavior is very essential and has a crucial role in the success of an organization. Thus, an organization needs to hone its capability to understand the elements which influence consumer behavior. If an organization understands the various branding factors effectively, it can influence the purchasing decision of consumers successfully.

\section{Factors which affect the Consumer Buying Behavior}

According to Kotler \& Armstrong. (2000), they identify the following factor which affects consumer behavior

\section{Cultural Factors}

Culture isa basic factor of the need and wants and influences the buying behavior to a great extent. Subculture can be stated as the group of society who usually share the similar principles that are based on various factors like nationalities, religion, racial groups, geographic locations, and social status in society.

\section{Social Factors}

Social factors also play a role up to some extent on the buying behaviour of consumers. Reference groups are persons belonging to people like family friends, relatives, or surrounding who directly impact the personal decision-making process, there are people in the group who have special characteristics and personality know an opinion leader, who can influence others. Most of the people behave according to the group they are surrounded by.

\section{Personal Factor}

The taste in clothes is not only age-related but can be related to occupation like blue-collar is more rugged as it involves workers in manufacturing, construction, or manual labor while white-collar clothes are more like business suits and ties as it involves work worker in teaching, professionals and managerial. These factors are related to buyers on a personal level. And include age, occupation, income, personality, and attitude.

\section{Psychological Factors}

The purchasing decision of consumers is affected by various psychological factors. Some of the prominent factors are perception, motivation, and beliefs, and attitude. Also, it is difficult to measure these factors as they are internal in nature

\section{Research Gap}

After a comprehensive reading of many review literature, it is found that there are a lot of studies already done in the field of consumer buying behavior. But, it's equally true that there have been very few research works done in the field of clothing products in India. So, to fill the void this study is being done.

\section{Research Aim and Objective}

This study is built on the knowledge that sometimes it's hard to distinguish the various factors of brandings that influence the way customers buy clothes from one brand and no other. Understanding variables like pricing, brand loyalty, quality, advertising, and brand awareness will help to comprehend how they change the consumer decision-making process. This 
study can help an organization to better understand the branding strategies and choose the most efficient strategies which can eventually help an organization to increase profits.

The objective of this research study is to gain anin-depth understanding and insight about the impact of various branding factors which influence consumer decision while purchasing clothes.

- To determine the factor which has the greatest impact on consumer buying behavior while purchasing clothes

- To understand the relationship between various branding factors and consumer buying behavior

- To examine the relationship between the socio-demographic factors and the decision to buy branded clothes

\section{Hypothesis}

Taking the objectives of the study into consideration i.e. to understand the impact of various branding factors on consumer purchasing behavior, the following hypothesis is formulated from the various construct

- Hypothesis 1: No significant relationship between the age and buying the branded clothes

- Hypothesis 2: No significant relationship between the income and buying the branded clothes

- Hypothesis 3: Priceis the most significant factor while buying clothes

- Hypothesis 4: Brand awareness significantly influence the consumer buying behavior while buying the clothes

- Hypothesis 5: Brand image significantly influence the consumer buying behavior while buying the clothes

\section{RESEARCH METHODOLOGY}

There are various attributes of branding but for this study, only five were considered i.e. brand image, brand awareness, brand loyalty, pricing, and advertisement. These attributes are crucial as customers look for them while making a buying decision in the clothing industry.

\section{Data Collection}

Data collection process involved, floating of questionnaires to various customers. The questionnaire was floated to 250 consumers, 207 consumers gave the necessary information and details required which was selected for the further analyzing process. 
Table 1: Socio-Demographic Profile of Respondents

\begin{tabular}{|c|c|c|c|}
\hline Profile & Particulars & Respondents & As Percent (\%) \\
\hline \multirow{2}{*}{ Gender } & Male & 96 & $48.4 \%$ \\
& Female & 111 & $53.6 \%$ \\
\hline \multirow{5}{*}{ Age } & $21-30$ Years & 186 & $89.9 \%$ \\
& $31-40$ Years & 16 & $7.7 \%$ \\
& $51-60$ Years & 3 & $1.4 \%$ \\
& Above 60 & 2 & $1 \%$ \\
\hline \multirow{5}{*}{ Occupation } & Dentist & 1 & $.5 \%$ \\
& Artist & 1 & $.5 \%$ \\
& Home Maker & 2 & $1 \%$ \\
& Private Service & 55 & $26.6 \%$ \\
& Public Service & 13 & $6.3 \%$ \\
& Retired Govt. Officer & 1 & $.5 \%$ \\
& Self Employed & 26 & $12.6 \%$ \\
& Students & 108 & $52.2 \%$ \\
\hline \multirow{5}{*}{ Income/Allowances } & Less than 5000 & 61 & $29.5 \%$ \\
& 5000 to 10000 & 41 & $19.8 \%$ \\
& 10000 to 30000 & 25 & $12.1 \%$ \\
& 30000 to 50000 & 33 & $15.9 \%$ \\
& Above 50000 & 47 & $22.7 \%$ \\
\hline
\end{tabular}

\section{Sampling}

Non-Random sampling method has opted and, a convenience sampling process was used for this research study.

\section{Scale Measures}

The questionnaire has 20 questions which are related to the various measures and constructs required for the research. The questionnaire further can be split into two parts: Section 1 consists of choices about demographic factors like age, gender, income, and profession. Section 2: consist of the construct which is chosen for the research study for measuring the various branding factors which effect the purchasing decision of consumers in the clothing industry. Most of the questions are analysed on a Likert scale (5-point scale) which range from (1=least agree to $5=$ most agree).

- Brand Image - The first four questions measure the Brand Image using questions like "I feel the image of the clothing brand I prefer to buy",

- Brand Loyalty -Brand Loyalty is measured by five-question like "How likely you will suggest the brand you prefer to others".

- Brand Awareness - The Brand Awareness is measured by asking four questions like "I can easily identify the brand I prefer"

- Pricing - The pricing is measured by asking 2questions like "Low prices of clothes increase my willingness to buy them"

- Advertising - The advertising is measured by asking 2 questions like, "How much does an advertisement influence you while selecting and buying a specific brand of clothes?"

- Consumer Buying Behavior - Consumer buying behavior is measured by asking 5 questions like"My society culture affects my buying behavior". 
To evaluate the data IBM SPSS software was used. For study, reliability test and factor analysis were used as it helps to examine the relationship between various variables. Also, Varimax with Kaiser normalization rotation was used. Exploratory factor analysis was done to observe the structure of the variables chosen for research. KMO measurement was (0.750) and Bartlett's test shown a positive result at the significance level $(\mathrm{p}=0.00)$.

Table 2: KMO and Bartlett's Test

\begin{tabular}{|c|c|c|}
\hline KMO Test for Sampling & & $\mathbf{. 7 5 0}$ \\
\hline & Approximate Chi-Sq. & 2240.799 \\
Bartlett's Test & df & 406 \\
& Significance (p) & .000 \\
\hline
\end{tabular}

The Cronbach alpha is coefficient which is helps to determine the intrinsic consistency or the correlation of variables in the research. For the reliability to get credibility, it should be greater than 0.70 . From the table, it can be observed that the entire construct has reliability greater than 0.70 and the overall reliability is 0.751 . Thus, it can be said that the data collected for the study is reliable.

Table 3: Summary Reliability and Factor Analysis

\begin{tabular}{|c|c|c|c|c|c|c|}
\hline Construct & Underlying Factor & Factor Loading & KMO Value & Cronbach Alpha & (N) Items & Mean \\
\hline Brand Awareness & $\begin{array}{l}\text { BA 1 } \\
\text { BA } 2 \\
\text { BA } 3 \\
\text { BA } 4\end{array}$ & $\begin{array}{l}.856 \\
.800 \\
.796 \\
.746\end{array}$ & .795 & .808 & 4 & 4.709 \\
\hline Brand Image & $\begin{array}{l}\text { BI } 1 \\
\text { BI } 2 \\
\text { BI } 3 \\
\text { BI } 4\end{array}$ & $\begin{array}{l}.852 \\
.843 \\
.810 \\
.645\end{array}$ & .735 & .719 & 4 & 4.107 \\
\hline Brand Loyalty & $\begin{array}{l}\text { BL } 1 \\
\text { BL } 2 \\
\text { BL } 3\end{array}$ & $\begin{array}{l}.857 \\
.837 \\
.760\end{array}$ & .782 & .797 & 3 & 3.876 \\
\hline Pricing & $\begin{array}{l}\text { P } 1 \\
\text { P } 2\end{array}$ & $\begin{array}{l}.899 \\
.662\end{array}$ & .655 & .648 & 2 & 3.934 \\
\hline Advertising & $\begin{array}{l}\text { Ad } 1 \\
\operatorname{Ad} 2\end{array}$ & $\begin{array}{l}.945 \\
.685\end{array}$ & .637 & .729 & 2 & 3.605 \\
\hline $\mathrm{CBB}$ & $\begin{array}{l}\text { CB } 1 \\
\text { CB } 2 \\
\text { CB } 3 \\
\text { CB } 4 \\
\text { CB } 5 \\
\end{array}$ & $\begin{array}{l}.888 \\
.861 \\
.815 \\
.615 \\
.532\end{array}$ & .718 & .808 & 5 & 3.755 \\
\hline
\end{tabular}

\section{DATA ANALYSIS}

In the research conducted, the dependent variable is the consumer buying behavior and the independent variable is branding. Since branding cannot be measured directly, it was divided into constructs like pricing, brand awareness, brand image, advertising, and brand loyalty. 
Table 4: People Who Prefer Branded Clothes

\begin{tabular}{|c|c|c|c|c|c|}
\hline Prefer Branded Clothes & 21-30 Years & 31-40 Years & 51-60 Years & 60+ Years & Total \\
\hline Yes (Count) & 111 & 8 & 3 & 0 & 122 \\
As \% & $91 \%$ & $6.6 \%$ & $2.5 \%$ & $0 \%$ & $100 \%$ \\
\hline No (Count) & 75 & 8 & 0 & 2 & 85 \\
As \% & $88.2 \%$ & $9.4 \%$ & $0 \%$ & $2.4 \%$ & $100 \%$ \\
\hline Total & 186 & 16 & 3 & 2 & 207 \\
\hline
\end{tabular}

Cross tabulation is used to analyze the socio-demographic variables. This non-parametric data analysis is a good technique to analyze the frequency distribution of more than two categorical variables. Below is a table of chi-square which shows, is there any relationship that exists among various variables.

Table 5: Cross Tabulation (Demographic Vs Buying Branded Clothes)

\begin{tabular}{|l|c|c|c|}
\hline Demographics & Chi-Sq & df & Asymp. Significance (2 Sided) \\
\hline Age & 5.531 & 3 & .137 \\
\hline Gender & .470 & 1 & .493 \\
\hline Income & 12.697 & 4 & .013 \\
\hline Occupation & 8.729 & 8 & .366 \\
\hline
\end{tabular}

Deployed cross-tabulation, to study the relation and the impact of demographics variables on consumer-branded clothes. The above table show socio-demographic variables like age, gender, income, and occupation. It is observed that pvalue (.137) for age is more than the significance value or the p value at 5\% thus it can be concluded that age doesn't have a significant relationship with buying the branded clothes. Thus, the null hypothesis is accepted

It is observed that the p-value (.013) for income is less than the significance value at $5 \%$ thus it can conclude that income has a significant relationship with buying the branded clothes. Thus, the null hypothesis is rejected

Table 6: Regression Coefficient

\begin{tabular}{|c|c|c|}
\hline & Beta Value & Significance \\
\hline P & .211 & .000 \\
\hline BI & .421 & .010 \\
\hline BL & .352 & .002 \\
\hline Ad & .247 & .000 \\
\hline BA & .375 & .007 \\
\hline
\end{tabular}

To prove the third hypothesis "Price is the most significant factor while purchasing the clothes ", used regression analysis and from the result $(\mathrm{B}=.211, \mathrm{Sig}=.000)$ it is observed that there is a significant effect of pricing on the consumer buying behavior but the price is not the most significant factor while purchasing the clothes. Thus, the null hypothesis is rejected. To prove the fourth hypothesis "Brand awareness significantly influences consumer buying behavior while purchasing clothes ", used regression analysis and from the result $(\mathrm{B}=.375$, Sig $=.007)$ it is observed that there is a significant impact of brand awareness on consumer buying behaviour when purchasing clothes. Thus, the null hypothesis is accepted. Further, to test the fifth hypothesis "Brand image significantly influences consumer buying behavior while purchasing clothes" used regression analysis and from the results $(\mathrm{B}=.421$, Sig $=.010)$ it is observed that there is a significant impact of brand image on the consumer buying behaviour when purchasing clothes. Thus, the null hypothesis is accepted. Also, from the correlation table, it can be observed, the two-construct brand loyalty and advertising are significantly different and have a weak correlation of .115. Thus, it can be assumed that advertising and brand loyalty are considered differently while purchasing clothes. 
Table 7: Correlation Between Variables

\begin{tabular}{|c|c|c|c|c|c|c|}
\hline & CBB & BI & BA & BL & Ads & PS \\
\hline CBB & 1 & & & & & \\
\hline BI & $.548^{*}$ & 1 & & & & \\
\hline BA & $.517^{*}$ & $.531^{*}$ & 1 & & & \\
\hline BL & $.436^{*}$ & $.517^{*}$ & $.394^{*}$ & 1 & & \\
\hline Ads & $.246^{*}$ & $.247^{*}$ & $.215^{*}$ & $.115^{*}$ & 1 & \\
\hline P & $.376^{*}$ & $.191^{*}$ & $.159^{*}$ & $.295^{*}$ & $.267^{*}$ & 1 \\
\hline
\end{tabular}

*Correlation is significant at .05 level (2-Tailed)

\section{FINDINGS}

Table 8: Brand Preference of Consumers

\begin{tabular}{|l|c|c|c|c|c|c|}
\hline \multicolumn{1}{|c|}{ Brand Preference } & Male & As (\%) & Female & As (\%) & Total & As (\%) \\
\hline Domestic Brand & 8 & $88.9 \%$ & 1 & $11.1 \%$ & 9 & $100 \%$ \\
\hline Domestic Brand with Foreign Labels & 44 & $51.8 \%$ & 41 & $48.2 \%$ & 85 & $100 \%$ \\
\hline Foreign Brands & 44 & $38.9 \%$ & 69 & $61.1 \%$ & 113 & $100 \%$ \\
\hline
\end{tabular}

Table 9: Factors Consumer Consider Before Buying a Clothing Brand

\begin{tabular}{|l|c|c|}
\hline \multicolumn{1}{|c|}{ Factors } & Mean & Std. Dev \\
\hline Quality & 4.42 & .876 \\
\hline Price & 4.24 & 1.126 \\
\hline Design & 4.21 & .876 \\
\hline Brand Name & 3.57 & 1.146 \\
\hline
\end{tabular}

\section{CONCLUSIONS}

This study presents the impact of various branding factors that affect consumer buying behavior while purchasing clothes. After analyzing the data, it is found that most of the branding factors have a strong relation with the buying behavior of the consumers while purchasing the clothes. Thus, this study can add some new facts to previous research. The branding factors which influence the buying decision are brand awareness, brand loyalty, brand image pricing, and advertising and it is found that brand image has the highest impact which can influence the decision making of the consumer while purchasing clothes $(\mathrm{Co}-\mathrm{rel}=.548, \mathrm{p}<.05)$. The second most important factor was brand awareness $(\mathrm{Co}-\mathrm{rel}=.517, \mathrm{p}<05)$, followed by brand loyalty (Co-rel=.436, p<05). However, pricing and advertisement have a weak relationship with consumer buying behavior (Co-rel=.376, Co-rel=.246, p<.05). Form the study, it can be inferred that consumers are heavily influenced by the brand image, this may be because people relate the brand image to the quality and they simply don't mind paying even more as long as the quality of product is good. The hypothesis also proved that there is no significant impact on the age group of consumers and their behavior towards buying branded clothes. On the other hand, it was observed that the income level affects the behavior of consumers toward buying branded clothes. Apart from these,Table11, depicts that most of the consumers prefer to the quality which was offered by the brand, followed by the price of the brand then design, and the least preference was given to brand name. Thus, we can conclude if a brand offers good quality clothes then it will be the deciding factor. Also, from the above Table 10, it can be noted that (54.58\%) of the consumers prefer to buy international brands like Wrangler/Levi's/Zara. (41.06\%) of the consumers prefer domestic brands with private labels like Van Heusen/ Louis Philippe/ Allen Solly Only (4.34\%) prefer domestic brands like Killer/Provogue/Shiv Naresh. The reason may be, the brand image and quality. Most of the people are unaware that Van Heusen/Louis Phillippe/ Allen Solly is a domestic brand. But the branding strategies followed by these brands make the 
consumer think that they are an international brand and create a perception that the quality offered by them will be good thus encouraging consumers to buy.

\section{DISCUSSION AND SCOPE FOR FUTURE}

In today's world branding is very crucial for the survival of any organization. And the way every individual perceives it is different but there are few factors that should be focused while deploying branding strategy like pricing strategy, brand image, etc. The present research is focused and limited to the Indian clothing industry. The majority of the sample involves the younger generation and their perception towards branding strategies like brand awareness and brand loyalty is much stronger than the Gen Y and Gen X. A well-structured and larger data set in terms of demography and sample size is recommended for future research. The scope of branding is too deep, so for further investigation, it is equally necessary to understand the consumer behavior and impact of branding in other developed markets.

\section{REFERENCES}

1. Aaker, D. A., (1991). "Managing brand equity capitalizing on the value of a brand name". New York: Free Press.

2. Agarwal, Z, Wani, S \&Senith, S. (2017). Impact of Brand on Consumer Buying Behavior. World Wide Journal of Multidisciplinary Research and Development, Volume 3(9), 1-6.

3. Gayatri Sasi Tampi \& Githa Heggde, "Impact of Organisational Initiatives on Internal Branding - Evidence from Indian it Organisations in Bangalore”, International Journal of Human Resources Management (IJHRM), Vol. 7, Issue 4,pp. 1-10

4. Ahuja, N. (2015). Affect of Branding on Consumer Buying Behavior: A Study in Relation to Fashion Industry. International Journal of Research in Humanities \& Social Sciences, 3(2),.

5. Ashraf, M, Naeem, M \&Shahzadi, M. (2017). Impact of Branding on Consumer Buying Behavior: An Evidence of Footwear Industry of Punjab, Pakistan. International Journal of Academic Research in Business and Social Sciences, Volume-VII (7),

6. Chaudhuri A. Consumption, emotion, and perceived risk: a macro analytic approach. J Bus Res 1997;39(2):81-92.

7. Chegini, F, Molan, S.B \&Kashanifar, S.S. (2016). An Examination of the Impact of Cultural Values on Brand Preferences in Tehran's Fashion Market. Procedia Economics and Finance, 36, 189-200.

8. Chovanová, H.H, Korshunov, A.I \&Babčanová, D. (2015). Impact of Brand on Consumer Behavior. Procedia Economics and Finance, 34(XX), 615-621.

9. Erdil, T.S. (2015). Affects of customer brand perceptions on store image and purchase intention: An application in apparel clothing. Procedia - Social and Behavioral Sciences, 207(XX), 196-205.

10. Farris, Paul W.W., Neil T. Bendle, Phillip E. Pfeifer, and David J (2010). Reibstein, Marketing Metrics: The Definitive Guide to Measuring Marketing Performance, Upper Saddle River, New Jersey: Pearson Education.

11. Grewal, D., Krishnan, R., Baker, J., Borin, N. (1998) "The affect of store name, brand name, and price discounts on consumers 'evaluations and purchase intentions", Journal of Retailing, 74(3): 331-352.

12. Hawkins, D. I., et al. (2010). "Consumer behavior." Implications for marketing strategy 5.

13. Hislop, M. 2001. An Overview of Branding and Brand Measurement for Online Marketers. Dynamic Logic's Branding, Vol. 101, pp. 1-22.

14. Jaggi, S \&Nim, D. (2019). Impact of Advertisements on Consumer Buying Behavior for Jewellery Purchase. International Journal of Recent Technology and Engineering (IJRTE), Volume-8 (4), 
15. Jefkins, F. (1973), “Advertising Made Simple”, W.H. Allen, London

16. Kahle, L.R. \& Kim, C.H. (2006) “Creating images and psychology of marketing communication.” New Jersey: Lawrence Erlbaum Associates, Inc., Publishers.

17. Keller, K. L. (1993). "Conceptualizing, measuring, and managing customer-based brand equity." the Journal of Marketing: 122.

18. Keller, K. L. (2003). "Building, measuring, and managing brand equity." Aufl., Upper Saddle River, NJ.

19. Keller, K.L. (1998), Strategic Brand Management: Building, Measuring and Managing Brand Equity, Prentice-Hall, Upper Saddle River, New Jersey

20. Khan Niazi GS, Siddiqui, Alishah, Hunjra AI. Affective Advertising and its Influence on Consumer Buying Behavior.Information Management and Business Review. 2012; p.114-119

21. Kotler P \& Armstrong. G. (2000) Principle of Marketing, 9th European edition, Financial time Prentice Hall, 2000

22. Kotler P., Armstrong G., Saunder J., and Wong, V, (1999) “Principle of marketing' (2nd edn) England; prentice hall.

23. Kotler, P.,Keller, K. L., Koshy, A., Jha, M., 2013. Marketing Management: A South Asian Perspective, 14thEdition.Imprint Pearson Education, 2013, 728 p.ISBN 9788131767160

24. Kumar, H.H, John, S.F \&Senith, S. (2014). A Study on factors influencing consumer buying behavior in cosmetic products. International Journal of Scientific and Research Publications, Volume 4(9), .

25. Labeaga, J.M., N. Lado, M. Martos. (2007). "Behavioral loyalty towards store brands", Journal of Retailing and Consumer Services, 14: 347-356.

26. Neritan Turkeshi \& Nuhi Sela, "The Role and the Importance of the Brand in the Development of the Enterprise ", BEST: International Journal of Humanities, Arts, Medicine and Sciences (BEST: IJHAMS), Vol. 3, Issue 11, pp. 79-86

27. Lim, C. .H, Kim, K\& Cheong, Y. (2016). Factors affecting sportswear buying behavior: A comparative analysis of luxury sportswear. Journal of Business Research, Volume-VIII-I

28. Loudon, D.; Della Bitta. (1986). A. Consumer Behavior. Concepts and Applications, New York: McGraw-Hill.

29. Oh, Haemoon (2000), "The Affect of Brand Class, Brand Awareness, and Price on Customer Value and Behavioral Intentions", Journal of Hospitality \& Tourism Research 24.2: 136-162.

30. Rossiter JR \& Percy L (1987). Advertising and Promotion Management. Singapore: McGraw-Hill.

31. Schmitt, B., (2012)," The consumer psychology of brands”, Journal of Consumer Psychology, 22: 7-17.

32. Farhaan Habib , "Brand Identity and its Impact on Consumer Behavior: Empirical Analysis “, IMPACT: International Journal of Research in Humanities, Arts and Literature (IMPACT: IJRHAL), Vol. 7, Issue 10, pp.69-84

33. Schmitt, B.H. (1999) Experiential Marketing. New York: The Free Press

34. Sehiffman, L.G \&Kanuk, L.L. (1997). Consumer Behavior. (6 ed.). New Jersey:

35. Singh, B. (2013). Impact of branding strategy on consumer buying behavior. Research Journal of Arts, Management \& Social Science, Volume-VIII-I (4)

36. Solomon, M.R. Bamossy, G. Askegaard, S. \& Hogg, M.K. (2010). “Consumer behavior: a European perspective.” 4th Edition. Essex: Pearson Education Limited. 
37. Solomon. Consumer behavior. 3rd ed. Prentice-Hall Englewood Cliffs, NJ; 1996, p.131-7.

38. Solomon. M.R. “Consumer Behavior: BUYING, HAVING, AND BEING.” 9TH Edition. Pearson education INC. New Jersey Aaker, D.A.,1991. 2011.

39. Thangamani, Wani, S \&Senith, S. (2019). Impact of Branding on Consumer Behavior. International Journal of Management, Volume 6(3),

40. Uggla, H. (2001) Organisation avvarumarke. Malmo: Liber Ekonomi Travis Daryi, Emotional Branding- How Successful Brands Gain the Irrational Edge, p.39

41. Veto Datta \& S. Vasantha, "Positioning of a Brand Through Advertising and Impact of Advertisement on Customers Preference “, BEST: International Journal of Management, Information Technology and Engineering (BEST: IJMITE), Vol. 3, Issue 8, pp. 35-42

42. Yoo B, Donthu N, Lee S. An examination of selected marketing mix elements and brand equity. J Acad Mark Sci 2000;28(2):195-211. 

